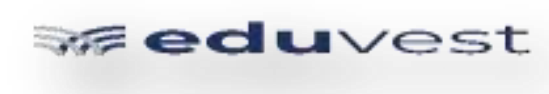

Eduvest - Journal of Universal Studies

Volume 2 Number 1, January, 2022

p- ISSN 2775-3735- e-ISSN 2775-

3727

\title{
ANALYSIS OF LABOR ABSORPTION IN EAST NUSA TENGGARA PROVINCE 2016-2020 PERIOD
}

\author{
Novi T. Kiak, Marselina Ratu, Maria I. H. Tiwu, Olivia Louise Eunike \\ Tomasowa \\ Nusa Cendana, University, Indonesia \\ Email: novi.kiak@staf.undana.ac.id,marselinaratu@staf.undana.ac.id, \\ Indrianitiwu@staf.undana.ac.id, olivia.tomasowa@staf.undana.ac.id
}

\begin{tabular}{ll}
\hline ARTICLE INFO & ABSTRACT \\
\hline Received: & This study analyzes the absorption of labor in East Nusa \\
December, 26th & Tenggara Province for the 2016-2020 period. The research aims \\
2021 & to identify sectors that have the power to absorb labor and the \\
Revised: & ability to compete in the 2016-2020 period; and find out how the \\
January, 17th & effect of economic growth on employment in East Nusa \\
2022 & Tenggara Province for the 2016-2020 period. The type of \\
Approved: & secondary data was obtained during the 2016-2020 observation \\
January, 18 & period. These data include GRDP based on constant prices in East \\
2022 & Nusa Tenggara Province for the 2016-2020 period and \\
& population data for those aged 15 years and over (labor data). \\
& The analytical tools used are Location Quotient (LQ), Shift Share \\
& (SS), Kindergarten Productivity, TK Elasticity, MRP, Klassen and \\
& Typology. The results of the LQ analysis show that the \\
& agricultural, forestry and fisheries sectors are sectors that are not \\
the leading sectors in absorbing labor during that period, the & study because it has an LQ value below 1. The results of the \\
& analysis that the shift-share analysis shows during the analysis \\
period 2016 to by 2020. In the province of East Nusa Tenggara, \\
the largest information and communication sector has the \\
largest competitive advantage, which is indicated by having a \\
higher nij value compared to other provinces sector and has the \\
largest number of employees.
\end{tabular}

KEYWORDS Kindergarten Absorption, Location Quotient, Shift Share, Kindergarten Productivity, Kindergarten Elasticity

\begin{tabular}{|c|c|}
\hline (c) & $\begin{array}{l}\text { This work is licensed under a Creative Commons } \\
\text { Attribution-ShareAlike } 4.0 \text { International }\end{array}$ \\
\hline & $\begin{array}{l}\text { Novi T. Kiak, Marselina Ratu, Maria I. H. Tiwu, Olivia Louise Eunike } \\
\text { Tomasowa. (2022). Analysis of Labor Absorption in East Nusa } \\
\text { Tenggara Province 2016-2020 Period. Journal Eduvest. Vol(Number): }\end{array}$ \\
\hline How to cite: & $173-181$ \\
\hline $\begin{array}{l}\text { E-ISSN: } \\
\text { Published by: }\end{array}$ & $\begin{array}{l}\text { 2775-3727 } \\
\text { https://greenpublisher.id/ }\end{array}$ \\
\hline
\end{tabular}




\section{INTRODUCTION}

One of the economic problems that always arises in the region is the problem of the availability of jobs that can absorb labor. This problem usually arises when the rate of population growth is greater than the rate of economic growth. The large number and growth of the labor force accompanied by this limited capacity will lead to unemployment. Ideally, high economic growth is followed by high employment absorption. One form of population participation is through employment opportunities which are opportunities for residents to carry out their functions as economic resources in the production process. The large number and growth of the labor force accompanied by this limited capacity will lead to unemployment.

Regional economic development efforts have a goal in addition to economic growth as well as efforts to reduce the number of unemployed, because otherwise the number of unemployed will continue to increase and disrupt the process of further regional development. Development in the field of manpower is an integral part of national development, so that labor problems that arise are also the impact of problems of national economic development. Discussions on employment cannot be separated from the population and the workforce. The number of working age population (15 years and over) in an area continues to grow along with the increase in population. The total population in East Nusa Tenggara Province in 2016 was 5,203,514 people and in 2020 it was 5,541,394 people, thus during that period there was an increase in the number of residents of 337,880 people. The working age population in East Nusa Tenggara Province in 2016 was 2,277,068 people and in 2020 it was 2,458,232 people, so there was an increase in the population of 181,164 people or $1.49 \%$. Large population growth which is usually followed by a growth in the labor force (Toossi, 2012). There will be serious problems with the absorption of labor if the increase in the labor force is not matched by the increase in labor absorption (Brückner \& Pappa, 2012).

(Tomasowa \& Pudjihardjo, 2011) suggests about the theory of economic basis that regional economic growth is highly dependent on external demand from outside the region. According to (Fin, 2017), the growth of some basic sectors will determine overall regional development, while the non-base sectors are only the consequences of regional development. Goods and services from the exported base sector will generate income for the region and increase consumption and investment (Banerjee, Cicowiez, \& Gachot, 2015). An increase in income will not only lead to an increase in demand for the basic sector, but will also increase demand for the non-base sector, which in turn will also encourage an increase in investment in the non-basic sector.

According to the Harrod-Domar theory in (Boianovsky, 2018), in order for an economy to continue to experience full use of its capital tools and achieve full employment opportunities from time to time (steady growth), a rate of increase in capital equipment and labor must be created equal to the desired growth rate (warranted). rate of growth). Therefore, in relation to regional economic development, the opening of the economy of a region is very important because it will facilitate the movement of capital and labor equipment from one region to another so that full use of capital tools and employment opportunities can occur from time to time.

Neo-classical theory suggests that the factors that will determine the growth rate of a country's economic growth are the increase in capital accumulation which includes investment in land, physical infrastructure and human capital, population and labor force growth, as well as technological progress technological progress) which is the most 
important source of economic growth (Eisner \& Nadiri, 1968). Technological progress can be in the form of saving workers or saving capital (Todaro \& Smith, 2000).

Therefore, this study seeks to systematically describe the absorption of labor in the province of East Nusa Tenggara so that it can be taken into consideration for local governments, especially in the preparation of economic and manpower planning and policies.

\section{RESEARCH METHOD}

To answer the research objectives proposed, namely to obtain an overview and understanding of regional economic conditions in employment, the following analytical methods can be used:

1. Analysis of Labor Elasticity is used to determine how much influence economic growth has on employment in TTS Regency - East Nusa Tenggara Province.

2. Analysis (1). Location Quotient (LQ), (2). MRP (overlay), (3). Klassen typology is used to determine the basic and non-basic sectors in employment.

3. Analysis of Labor Productivity. This analysis is used to calculate the output produced by labor by sector.

To assist the analysis of changes in the structure of the workforce, several additional indicators such as productivity and labor elasticity are needed. Labor productivity is calculated by the formula (see (Hasnah, 2016)):

$$
P_{1}=\frac{P D R B}{K k_{i}}
$$

Another indicator to help analyze changes in the structure of the workforce is the elasticity of the workforce. Labor elasticity is a value that shows a percentage indicating a change in the number of workers that can be absorbed in sector i. The elasticity of employment opportunities is formulated as follows:

$$
E K K_{i}=\frac{\% \Delta K K}{\% \triangle P D R B_{i}}
$$

Where :

Pi: Labor productivity in sector $\mathrm{i}$

EKKi: elasticity of employment in sector $\mathrm{i}$

KK: the average growth rate of labor absorption in sector i in TTS Regency in 20052010 ,

GDP: the average economic growth rate in TTS Regency in 2005-2010.

EKKi is the elasticity of employment opportunity in sector i of TTS Regency. If the elasticity value:

EKK 1 indicates the growth rate of labor absorption is greater than the rate of labor productivity.

EKK 1 shows that the growth of labor absorption is smaller than the rate of labor productivity.

$\mathrm{EKK}=1$ indicates a constant level of productivity

The LQ technique aims to measure the comparative advantage of an area in determining its base sector. In this analysis, LQ is calculated based on the number of workers by comparing the workforce in an area (district/city) with workers in the comparison area (province). The formula used is (Arsyad, 1999):

$$
L Q=\frac{\left(E_{i j} / E_{j}\right)}{\left(E_{i n} / E_{n}\right)}
$$


Where:

Eij is a sector $\mathrm{i}$ worker in district/city $\mathrm{j}$

$\mathrm{Ej}$ is the total workforce in the district/city $\mathrm{j}$

Ein is a provincial sector worker.

En is the total workforce of the province.

The Growth Ratio Model (MRP) is used to obtain the reference area growth ratio (RPr) and study area growth ratio (RPs) with the formula:

$$
R P_{r}=\frac{\Delta \operatorname{EiR} / \operatorname{EiR}(t)}{\Delta E R / E R(t)}
$$

and

$$
R P_{S}=\frac{\Delta E_{i j} / E_{i j}(t)}{\Delta \operatorname{EiR} / \operatorname{EiR}(t)}
$$

Where :

EiR is the change in the workforce of sector $i$ in the reference area,

$\operatorname{EiR}(t)$ is the workforce of sector $\mathrm{i}$ in the reference area of year $\mathrm{t}$,

ER is the total workforce change in the reference area,

$\mathrm{ER}(\mathrm{t})$ is the total workforce in the reference area year $(\mathrm{t})$,

Eij is the change in the workforce of sector $\mathrm{i}$ in the study area,

Eij(t) is the workforce of sector $\mathrm{i}$ in the study area in year $\mathrm{t}$.

Overlay analysis is intended to see a description of potential economic activities based on growth criteria (MRP) and contribution criteria (Location Quotient) which are further classified into 4 (four) possibilities in the Overlay analysis related to the description of the economic structure. The four possibilities are (MT, 1999).

1. Growth (+) and contribution (+), shows a very dominant sector, both growth and contribution;

2. Growth (+) and contribution (-), indicating a sector with dominant growth but a small contribution;

3. Growth (-) and contribution (+), indicating a sector with small growth but large contribution;

4. Growth (-) and contribution (-), indicate a sector that has no potential, both in terms of growth criteria and contribution.

In this case, Klassen's Typology analysis uses labor data. This aims to see the position of the economic sectors that have the potential to absorb labor in Kupang City.

In Klassen's Typology analysis, the observed sector is also divided into four classifications, namely the fast-growing and fast-growing sector (high growth and low income), the advanced but depressed sector (high income but low growth), the fastgrowing sector (high growth but low income). ), and relatively lagging sectors (low growth and low income).

\section{RESULT AND DISCUSSION}

The results of the analysis of the Location Quotient of Labor since 2016 2020 are in full in Table 1.

Table 1 LQ Results by Field of Business In East Nusa Tenggara Province, 2016 -

2020

\begin{tabular}{rlrrrrrr} 
Category & \multicolumn{1}{c}{ Description } & $\mathbf{2 0 1 6}$ & $\mathbf{2 0 1 7}$ & $\mathbf{2 0 1 8}$ & $\mathbf{2 0 1 9}$ & $\mathbf{2 0 2 0}$ & AVERAGE \\
\hline & Agriculture, Forestry and & & & & & & \\
A & Fisheries & 0,60 & 0,54 & 0,53 & 0,56 & 0,52 & 0,55 \\
\hline B & Mining and excavation & 0,97 & 1,04 & 0,95 & 1,06 & 1,03 & 1,01 \\
\hline C & Processing industry & 1,78 & 1,59 & 1,64 & 1,47 & 12,92 & 3,88 \\
\hline
\end{tabular}




\begin{tabular}{clcccccc}
\hline & Electricity and Gas & & & & & & \\
D & Supply & 0,73 & 1,22 & 1,42 & 1,77 & 1,37 & 1,30 \\
\hline & Water Supply, Waste & & & & & & \\
Management, Waste and & & & & & & \\
E & Recycling & 1,48 & 1,59 & 1,51 & 1,19 & 1,18 & 1,39 \\
\hline F & Construction & 2,21 & 2,28 & 2,37 & 2,08 & 1,94 & 2,17 \\
\hline & $\begin{array}{l}\text { Wholesale and retail } \\
\text { trade, Repair of Cars and }\end{array}$ & & & & & & \\
G & Motorcycles & 0,85 & 1,08 & 1,17 & 1,04 & 1,01 & 1,03 \\
\hline H & $\begin{array}{l}\text { Transportation and } \\
\text { Warehousing }\end{array}$ & 3,26 & 2,04 & 2,28 & 2,34 & 18,59 & 5,70 \\
\hline$\quad \begin{array}{l}\text { Provision of } \\
\text { Accommodation and }\end{array}$ & & & & & & \\
I & Drinks & 1,00 & 1,16 & 1,07 & 0,99 & 0,89 & 1,02 \\
\hline & TOTAL & $\mathbf{1 , 0 0}$ & $\mathbf{1 , 0 0}$ & $\mathbf{1 , 0 0}$ & $\mathbf{1 , 0 0}$ & $\mathbf{1 , 0 0}$ & $\mathbf{1 , 0 0}$ \\
\hline Source: Data Processed, 2021 & & & & & &
\end{tabular}

Source: Data Processed, 2021

From the LQ value in Table 1, it can be seen that the agricultural sector; forestry, and fisheries are not among the sectors that excel in absorbing labor in East Nusa Tenggara Province with an LQ value $<1$ for the 2016 - 2020 research period. the transportation and warehousing sector, and for other sectors it is also a superior sector for employment.

The use of the Growth Ratio Model (MPR) is divided into 2 (two), namely the reference area growth ratio (RPr) and the study area growth ratio (RPs). Based on the results of the MRP analysis, it shows that the growth rate of labor and the contribution of labor generated by the sector in East Nusa Tenggara Province has a small growth rate, the growth rate of the same sector at the national level, indicates that most of the sectors in East Nusa Tenggara Province have low growth rates. small growth but big contribution;

Based on the analysis of the Klassen Typology of East Nusa Tenggara Province with a sectoral workforce approach, it can be seen that the Manufacturing Industry sector; the electricity and gas procurement sector; wholesale and retail trade, car and motorcycle repair sector; The transportation and warehousing sector is classified as a developed sector and is growing rapidly. For the Mining and Quarrying sector, the Water Supply sector, Waste Management, Waste and Recycling, the construction sector, the Accommodation and Food and Drink Provision sector And the Agriculture, Forestry and Fisheries sectors are relatively lagging sectors. The data is then grouped according to the Klassen Typology classification as presented in the following table:

Table 2 Klassen Typology Based on Sectoral Kindergarten Approach in East Nusa Tenggara Province

\begin{tabular}{ccc}
\hline \multirow{2}{*}{ Growth rate $(\mathbf{R})$} & $\mathbf{L}$ Sector Contribution \\
\cline { 2 - 3 } & $\begin{array}{c}\text { Sector developed and growing } \\
\text { rapidly } \\
\mathbf{R} \mathbf{i}>\mathbf{R}\end{array}$ & $\begin{array}{c}\text { Sector developed but } \\
\text { depressed } \\
(\mathrm{C}, \mathrm{D}, \mathrm{G}, \mathrm{H})\end{array}$ \\
\hline $\mathbf{R} \mathbf{i}<\mathbf{R}$ & $\begin{array}{c}\text { Potential sector/can develop } \\
\text { rapidly } \\
\end{array}$ & $\begin{array}{c}\text { Relatively lagging sector } \\
(\mathrm{A})\end{array}$ \\
\hline
\end{tabular}

Source: Processed data

Information : A: Agriculture, Forestry and Fisheries; B: Mining and Quarrying; C: Processing Industry; D: Electricity and Gas Procurement; E: Water Supply, Waste Management, Waste and 
Recycling; F: Construction; G: Wholesale and retail trade, Repair of Cars and Motorcycles; H: Transportation and Warehousing; I: Provision of Accommodation and Food and Drink

In this case, labor is one of the factors of production that plays an important role in the formation of added value of an economic activity. so to see a picture of how much added value is provided by each worker in an economic activity, it can be seen by calculating labor productivity. The results of the calculation of labor productivity in East Nusa Tenggara Province from 2016 to 2020 are explained below.

Table 3 Labor Productivity Calculation Results East Nusa Tenggara Province, 2016-2020

\begin{tabular}{|c|c|c|c|c|c|c|c|}
\hline $\begin{array}{l}\text { DESCRIPTIO } \\
\mathbf{N}\end{array}$ & BUSINESS FIELD & 2016 & 2017 & 2018 & 2019 & 2020 & Average \\
\hline 1 & $\begin{array}{l}\text { Agriculture, Forestry, Plantation, } \\
\text { Fishery/Agriculture, Forestry, } \\
\text { Estate,Fishery }\end{array}$ & 31,11 & 28,25 & 27,05 & 29,65 & 27,26 & 28,67 \\
\hline 2 & Mining And Quarrying & 50,48 & 54,18 & 48,60 & 56,12 & 53,63 & 52,60 \\
\hline 3 & Manufacturing Industry & 92,79 & 82,84 & 84,43 & 77,49 & 675,30 & 202,57 \\
\hline 4 & $\begin{array}{l}\text { Electricity, Gas and } \\
\text { Water/Electricity, Gas and Water }\end{array}$ & 38,19 & 63,81 & 72,96 & 93,60 & 71,72 & 68,06 \\
\hline 5 & Building/Construction & 77,12 & 83,06 & 77,75 & 62,84 & 61,46 & 72,45 \\
\hline 6 & $\begin{array}{l}\text { Wholesale And Retail Trade, } \\
\text { Restaurant/Wholesale And Retail } \\
\text { Trade, Restaurant }\end{array}$ & 115,05 & $\begin{array}{c}118,7 \\
1\end{array}$ & $\begin{array}{c}121,7 \\
9\end{array}$ & $\begin{array}{c}109,9 \\
4\end{array}$ & 101,13 & 113,32 \\
\hline 7 & $\begin{array}{l}\text { Transportation, Warehousing, } \\
\text { Communication / Transportation, } \\
\text { Communication, Warehousing }\end{array}$ & 44,22 & 56,33 & 60,30 & 54,97 & 52,95 & 53,76 \\
\hline 8 & $\begin{array}{l}\text { Finance, Insurance, Rental and } \\
\text { Building Business, Land, and } \\
\text { Corporate Services / Financing, } \\
\text { Insurance, Real Estate and Business } \\
\text { Services }\end{array}$ & 169,74 & $\begin{array}{c}106,6 \\
1\end{array}$ & $\begin{array}{c}117,4 \\
0\end{array}$ & $\begin{array}{c}123,3 \\
6 \\
\end{array}$ & 971,58 & 297,74 \\
\hline 9 & $\begin{array}{l}\text { Community, Social, and Personal } \\
\text { Services }\end{array}$ & 52,05 & 60,49 & 55,00 & 52,47 & 46,73 & 53,35 \\
\hline & Total & 670,7 & 654,3 & 665,3 & 660,4 & $\begin{array}{c}2.061 \\
8 \\
\end{array}$ & 942,5 \\
\hline
\end{tabular}

The table above shows that the highest average productivity during the study period was achieved by the Finance, Insurance, Leasing and Building, Land, and Corporate Services business fields. The lowest productivity is in the sector/business field of Agriculture, Forestry, Plantation, Fisheries. The average productivity for all sectors is 942.5. This means that each worker on average produces an output or contribution to GRDP of Rp. 942.5 million. The sectors/ business fields of Finance, Insurance, Rental and Building Business, Land, and Corporate Services in East Nusa Tenggara Province showed the highest productivity with 297.74 .

Economic growth has an influence on the workforce in the area concerned, namely in the form of growth in labor productivity and labor absorption (Cai \& Wang, 2010). The effect of economic growth on employment is carried out by analyzing the elasticity of labor. From table above it can be seen that in East Nusa Tenggara Province the highest average elasticity during the study period was achieved by the Finance, Insurance, Rental and Building Businesses, Land, and Corporate Services sectors/business fields, while the electricity, gas and electricity sector/business fields 
company water shows the lowest elasticity. The elastic (sensitive) sectors in the absorption of labor are the mining and quarrying sector; processing industry sector; building sector; the trading, wholesale and retail sector of Restaurants; and the financial, insurance, rental and building business, land and corporate services sectors. The sector that has the highest elasticity is the Finance, Insurance, Rental and Building Business, Land, and Corporate Services sector at 4.8, this means that if the economy in this sector grows by 1 (one)\% per year it can cause an increase in employment in the sector. The average is $4.8 \%$ per year.

Table 5 Calculation of Labor Elasticity Against GRDP in TTS Regency, 20052010

\begin{tabular}{|c|c|c|c|c|c|c|}
\hline Category & Description & 2017 & 2018 & 2019 & 2020 & Average \\
\hline 1 & $\begin{array}{c}\text { Agriculture, Forestry, Plantation, } \\
\text { Fishery/Agriculture, Forestry, } \\
\text { Estate,Fishery }\end{array}$ & $-0,92$ & $-6,13$ & 3,57 & 2,12 & $-0,3$ \\
\hline 2 & Mining And Quarrying & 2,00 & $\mathbf{3 , 8 3}$ & 6,81 & $\mathbf{0 , 1 0}$ & 3,2 \\
\hline 3 & Manufacturing Industry & 2,62 & $\mathbf{0 , 7 8}$ & 3,63 & 10,82 & 4,5 \\
\hline 4 & $\begin{array}{l}\text { Electricity, Gas and Water/Electricity, } \\
\text { Gas and Water }\end{array}$ & $-3,65$ & 1,55 & $-3,62$ & $-3,01$ & $-2,2$ \\
\hline 5 & Building/Construction & $-2,73$ & 4,55 & 11,11 & 0,56 & 3,4 \\
\hline 6 & $\begin{array}{c}\text { Wholesale And Retail Trade, } \\
\text { Restaurant/Wholesale And Retail Trade, } \\
\text { Restaurant }\end{array}$ & 0,44 & 0,76 & 3,45 & 4,05 & 2,2 \\
\hline 7 & $\begin{array}{c}\text { Transportation, Warehousing, } \\
\text { Communication / Transportation, } \\
\text { Communication, Warehousing }\end{array}$ & $-7,40$ & 0,25 & 4,56 & 6,22 & $\mathbf{0 , 9}$ \\
\hline 8 & $\begin{array}{c}\text { Finance, Insurance, Rental and Building } \\
\text { Business, Land, and Corporate Services / } \\
\text { Financing, Insurance, Real Estate and } \\
\text { Business Services }\end{array}$ & 11,76 & $-2,63$ & 0,12 & 10,14 & 4,8 \\
\hline 9 & $\begin{array}{c}\text { Community, Social, and Personal } \\
\text { Services }\end{array}$ & $-1,89$ & $\mathbf{0 , 0 1}$ & 2,25 & $-4,66$ & $-1,1$ \\
\hline & Total & 0,88 & 1,64 & $-0,35$ & 1,76 & 1,0 \\
\hline
\end{tabular}

Source: Data Processed (2021)

According to the Harrod-Domar theory, in order for an economy to continue to experience full use of its capital tools and achieve full employment opportunities from time to time (steady growth), a rate of increase in capital equipment and labor must be created equal to the desired growth rate (warranted). rate of growth). Therefore, in relation to regional economic development, the opening of the economy of a region is very important because it will facilitate the movement of capital and labor equipment from one region to another so that full use of capital tools and employment opportunities can occur from time to time. (Kuncoro, 1919) says that the new paradigm of regional economic development for job opportunities is that jobs must develop jobs that are suitable for local residents.

Various theories of economic growth that have been described are able to explain the state of the economy in TTS Regency (Sanam, Nugraha, \& Rero, 2021). The importance of finding the base/leading sector to increase the distribution of income from outside the region, observing the components that affect employment absorption, observing production growth associated with labor productivity and labor elasticity.. 
Based on the theories that have been put forward, that the basis for developing the regional economy lies in the ability of the region to grow and develop in accordance with its endowment factors. The success of development is also shown by the creation of job opportunities that can provide welfare for the community (Nunan, 2014).

Based on the results of the discussion, it can be said that there are still gaps in economic growth. Manpower is one of the important components in the economic growth of a region, in TTS Regency the absorption rate of its workforce is not followed by increasing labor productivity in the economic sector. This shows that the development of economic sectors to maximize employment is needed to create a balanced economic system.

\section{CONCLUSION}

The results of this study indicate that transportation and warehousing are the most superior sector in employment and the sector that has the highest elasticity value so that the Finance, Insurance, Rental and Building Business, Land, and Corporate Services sectors have a major influence on economic growth and absorption. labor. In terms of labor productivity in the Finance, Insurance, Rental and Building Business, Land, and Corporate Services sectors/business fields, the total output/production continues to increase with an average growth during that period of 942.5. The sectors/ business fields of Finance, Insurance, Rental and Building Business, Land, and Corporate Services in East Nusa Tenggara Province showed the highest productivity with 297.74

\section{REFERENCES}

Arsyad, Lincolin. (1999). Ekonomika Pembangunan. Edisi pertama. Bagian Penerbitan STIE-YKPN. Yogyakarta.

Banerjee, Onil, Cicowiez, Martin, \& Gachot, Sébastien. (2015). A quantitative framework for assessing public investment in tourism-An application to Haiti. Tourism Management, 51, 157-173.

Boianovsky, Mauro. (2018). Beyond capital fundamentalism: Harrod, Domar and the history of development economics. Cambridge Journal of Economics, 42(2), 477504.

Brückner, Markus, \& Pappa, Evi. (2012). Fiscal expansions, unemployment, and labor force participation: Theory and evidence. International Economic Review, 53(4), $1205-1228$.

Cai, Fang, \& Wang, Meiyan. (2010). Growth and structural changes in employment in transition China. Journal of Comparative Economics, 38(1), 71-81.

Eisner, Robert, \& Nadiri, M. Ishaq. (1968). Investment behavior and neo-classical theory. The Review of Economics and Statistics, 369-382.

Fiń, Anna. (2017). Between Neighbors-Between Immigrants Poles and Ukrainians in the United States During the Time of the Cold War: A Few Reflections. Ad Americam. Journal of American Studies, (18), 35-50.

Hasnah, Nurbeti. (2016). Analisis pertumbuhan ekonomi dan penyerapan tenaga kerja di Kabupaten Sleman Propinsi DIY. Universitas Gadjah Mada.

Kuncoro, Mudrajad. (1919). Otonomi dan pembangunan daerah: reformasi, perencanaan, strategi, dan peluang. - .

MT, Ir Maulana Yusuf M. S. (1999). “ Model Rasio Pertumbuhan (0MRP)" sebagai Salah Satu Alat Analisis Alternatif dalam Perencanaan Wilayah dan Kota (Aplikasi Model: Wilayah Bangka-Belitung). Economics and Finance in Indonesia, 47, 219- 
234.

Nunan, Fiona. (2014). Wealth and welfare? Can fisheries management succeed in achieving multiple objectives? A case study of $\mathrm{L}$ ake $\mathrm{V}$ ictoria, $\mathrm{E}$ ast $\mathrm{A}$ frica. Fish and Fisheries, 15(1), 134-150.

Sanam, Syul Rosli, Nugraha, Yudha Eka, \& Rero, Laurensius Sandro. (2021). Participation of Local Community in Supporting East Nusa Tenggara Priority Programs. International Conference on Applied Science and Technology on Social Science (ICAST-SS 2020), 273-277. Atlantis Press.

Todaro, Michael P., \& Smith, Stephen C. (2000). Economic Development 7th. Harlow: Addison-Wesley.

Tomasowa, Olivia Tomasowa Louise Eunike, \& Pudjihardjo, Muhammad. (2011). Analisis Penyerapan Tenaga Kerja Di Kota Kupang Propinsi Nusa Tenggara Timur Tahun 2005-2010. Jurnal Ekonomi Pembangunan, 9(1), 107-121.

Toossi, Mitra. (2012). Labor force projections to 2020: A more slowly growing workforce. Monthly Lab. Rev., 135, 43. 